entrance examination than the public universities require, Azad's fees are an obstacle for many Iranians. The creation of Azad University has alleviated the pressure on public universities to supply a growing youth population with higher degrees (there are currently three million university students in Iran), but since the economy has been characterized by a high unemployment rate (Iı\%) graduates of Azad cannot be guaranteed to have a better chance of finding employment than graduates from public universities (I out of ro unemployed holds a university degree).

Moreover, Azad focuses purely on meeting the growing need for university degrees and does not provide its graduates with professional career counseling (higher education institutes in Iran lack career-planning services). Therefore, many students after graduation may not possess a clear idea of what they can do with their university degrees. As the brain drain persists in Iran, perhaps many of Azad's graduates leave the country to pursue advanced degrees or work abroad.

\section{Seeking Autonomy: French Universities Against the Jacobins}

\section{Christine Musselin}

Christine Musselin is Director of the Centre de Sociologie des Organisations (Sciences Po and CNRS), 19 rue Amélie 75007, Paris, France. Email:c.musselin@cso.cnrs.fr.

ince the Imperial University of Napoleon, founded in I808, only four higher education laws have been passed in France: in I896, an unsuccessful attempt to introduce the Humboldtian model in France; in I968, the Faure act, after the student demonstrations of May I968; in I984, the Savary act aimed at amending the Faure act; and finally the new Pécresse act, also called LRU (Loi relative aux Libertés et Responsabilités des Universités). All these acts have at least two points in common. First, they all aimed at transforming the governance of French universities rather than the whole higher education system. Second, they all provided universities with autonomy-a main issue often at stake in the discussions preceding the adoption of these acts.

The diagnosis of French universities suffering from lack of autonomy was central in the debates at the end of the igth century. The same diagnosis was again essential in most of the reflections led by a group of French academics some years before the events of May I968, during the second colloquium of Caen in I966. In the act voted six months after May I968,
Edgar Faure allocated administrative, budgetary, and pedagogical autonomy to the newly (re)created French universities. Autonomy was again reaffirmed in the Savary act of I984. Nevertheless autonomy remained on the agenda, in 2007, when Nicolas Sarkozy was elected.

\section{Favorable Institutional Settings}

When looking at the reasons why the previous acts had failed, one could anticipate a more efficient result from the LRU: many of the previous obstacles seemed to be erased. In the book I wrote on the "long march" of French universities, I explained the failure of the I896, I968, and I984 acts in making universities autonomous by the fact that they all focused on universities and not on the French "university configuration" as a whole. Thus, these acts sought to change university governance but not the management of the academic profession or the comanagement relationships the ministry had developed since Napoleon, with a centrally organized academic profession. The disciplines and their vertical and centralized structure remained the main interlocutors of the ministry while universities were marginal partners. In 2007, three factors raised the belief that this could change.

The four-year contracts introduced by the end of the ig8os between the ministry and each university had weakened the corporatist comanagement between the disciplines and the state and fostered the recognition of universities by the ministry administration. It also pushed university presidents to have an active role in the preparation of their institution's fouryear strategic plan. As a whole, by the beginning of 2000 , French universities had become much less anomic and ungoverned than they were 20 years earlier.

Not only providing administrative and budgetary autonomy, the LRU also contained the germs for universities to become more autonomous in the management of their human resources, therefore transforming the management of the academic profession. In terms of positions, the payroll up to now managed by the ministry was to be included in the operating budgets, thus allowing each university to decide on the reallocation of posts or the nature of a post (junior or senior, for instance). In terms of staff, some of the already existing possibilities (such as the allocation of bonuses or decisions on some promotions) were extended and new dispositions included in the act, such as the possibility to renegotiate the teaching, research, and service duties of academics.

One year before the LRU, another act (Loi de programme pour la recherche) was aimed at transforming the French research system so as to put universities at its center, by reducing the prerogatives of the national research institutions (such as the CNRS, Centre National de la Recherche Scientifique). On the one hand, a research council (the Agence Nationale de la Recherche) was created to manage grants run by the ministry and the national research institutions. On the other, the evaluation of the research units of the latter, was transferred to a newly created evaluation agency, the AERES (Agence 
d'Evaluation de la Recherche et de l'Enseignement Supérieur). During the same period, the two candidates to the French presidency promised to increase considerably the budgets for universities and research and to transform universities into major actors of the French higher education system.

In these favorable institutional settings, the LRU was passed four months after Nicolas Sarkozy's election. By January 2009, 20 universities implemented the new act and became responsible for all their budgets, including salaries. All other universities were to do the same within the five subsequent years.

\section{The Jacobins Regained Influence}

While many people assumed the turn toward more institutional autonomy had been obtained, a combination of factors allowed a revolutionary Jacobin front to coagulate against these reforms. Within a few months, the context described above changed dramatically. Four events in particular provoked demonstrations and contestation that forced the French minister to accept some backtrackings. First, during the fall of 2008 a decree was prepared to transform the rules regulating the French academic corps since 1984, to empower French universities and their presidents in the management of the academic staff, but this provoked fears. The decree, for instance, introduced the possibility to reduce teaching duties for academics involved in research activities but did not say a word about academics strongly involved in teaching. Yet, French universities

The two candidates to the French presidency promised to increase considerably the budgets for universities and research and to transform universities into major actors of the French higher education system.

are open to all baccalaureat holders and thus have to face strong pedagogical issues. Second, the ministry launched a reform of the training of secondary school teachers, which was immediately severely contested by academics involved in these training programs and by the students attending them.

A student-academic coalition against the reforms thus became possible and started to be active. Third, about the same moment, in the allocation of the 2009 university budgets, a new budgetary process was introduced that led to cuts in some universities, while the ministry claimed for months that the French higher education and research budgets have never been so high. Furthermore, cuts in the number of positions were implemented to participate in the general policy aimed at reducing the number of civil-servant positions. While the cuts in higher education were far from respecting the rule of "one post left for two retirements," which applies to the French state administration, this policy change was nevertheless cruelly resented by the universities and university presidents who feared it would be the drop that breaks the camel's back. But, fourth, the drop came from elsewhere: on January 22, 2009, President Sarkozy provided a discourse in which he fustigated the French research production and used rather derogatory terms. This pronouncement brought onto the streets all those who were against the decree and/or the reform of high school teachers' training, and/or the cuts, and/or the LRU, and/or the reform of the research system, and /or Sarkozy.

At that very moment, a bizarre coalition took place between the left-wing unions of academics and the right-wing law professors who all fought against the decree that would have allowed the universities to manage their academic staffs.

At that very moment, a bizarre coalition took place between the left-wing unions of academics and the right-wing law professors who all fought against the decree that would have allowed the universities to manage their academic staffs. Both groups pleaded for giving the CNU - the central national body involved in the management of academic careers since the Igth century (but which had less and less power since i992)the responsibility, every four years, to assess the research, teaching, and service activities of the 63,000 academicsmaîtres de conférences and professors. The latest version of the decree adopted in late April restrains the scope of decision for universities in the management of their staff.

The concrete implementation of the decree as well as the capacity of university presidents in informally expanding their formal prerogatives will of course be decisive for French universities to become more autonomous, if further restrictions are not obtained by the still ongoing contestations.

\section{The Impact of the UK Research} Assessment Exercise

\section{Michael Shattock}

Michael Shattock is visiting professor at the Institute of Education, University of London. E-mail: shattock@he.u-net.com.

The results of the latest, and probably the last, Research 1 Assessment Exercise (RAE) in the United Kingdom were announced in December 2008, and the financial outcomes for universities were confirmed in March 2009. Each of the previous RAEs (1986, I989, I992, I996, 200I) have cited winners 